Clinical Electroencephalography

By Dr. Robert Cohn. Pp. vii +639. (New York and London: McGraw-Hill Book Co., Inc., 1949.) $119 s$.

7 HIS book-which is a compilation of recordings

taken by the author over some years-must have a very limited field of interested readers. The first twenty-four pages are devoted to general considerations concerning electro-encephalography: of the remaining six hundred-odd pages, about three hundred are devoted to encephalograms, with twelve tracings per page. Few enthusiasts can be so stalwart as to make their way through these thousands of tracings.

The recordings are arranged in chapters, commencing with those clinical conditions which give the most precisely determined electric correlations, followed by conditions where the tracings are not so clearly delineated. Clinical histories for each set of recordings are given, together with 'impressions' concerning the recordings.

The book is an indication of the mass of material which the author has studied. A list of books and articles which the author recommends for reference reading is given at the end of the book.

The Chemistry and Technology of Enzymes

By Dr. Henry Tauber. Pp. viii +550. (New York: John Wiley and Sons, Inc.; London: Chapman and Hall, Ltd., 1949.) 45s. net.

$\mathrm{N}$ this book, the author has put together in a 1 revised form his two previously published works on "Enzyme Chemistry" (which appeared as a mimeographed monograph) and on "Enzyme Technology". Users of the former will be glad to see it in a more permanent and readable form. As the first part of this volume, it now offers in some 260 pages an excellent and up-to-date brief review of enzyme chemistry, which gives clear instructions for the preparation of many pure enzymes and for their estimation.

The second part of the book, on "Enzyme Technology", follows the same lines as its predecessor; but it has been brought up to date and will be very useful to all who are concerned with the industrial use of enzymes. The author interprets enzymology very widely-for example, his chapter on the production of antibiotics such as penicillin and streptomycin. The magnitude of these new industries is indicated by the statement that the production of penicillin in the United States in 1947 was twenty tons, and no doubt is by now much greater. Other interesting chapters deal with yeast, mould and bacterial fermentations, and recent developments in their industrial exploitation. J. A. V. Butuen

\section{Biology and Man}

By Dr. Francis G. W. Knowles. (Harrap's Torch Books.) Pp. 304. (London: George G. Harrap and Co., Ltd., 1950.) 10s. 6d. net.

7 HE senior biology master at Winchester College has already built up a sound reputation as the author of several successful biology text-books for schools. His latest work is aimed at the general reader, and in it he seeks to interpret the relationships between various forms of life. For this purpose the book is divided into two parts, the first dealing with some of those animals and plants which directly affect man, and the second with the study of the anatomy, functions and evolution of man's body.
The arrangement of the text is along traditional lines, except that two separate chapters are devoted to the biology of the potato and wheat; the author might have come nearer to his general purpose if these chapters had been devoted to the biology of the breakfast or lunch table. In his epilogue, too, which describes the economic and medical value of biology to man, the author might have interested a larger audience if he had devoted more attention to the sociological implications of biology. The book is admirably illustrated with line-drawings and diagrams. T. H. H.

\section{How Your Body Works}

By Dr. Geoffrey H. Bourne. Pp. xvi $+228+16$ plates. (London: Sigma Books, Ltd., 1949.) 12s. 6d. net.

THE increasing number of books on elementary I physiology now appearing may be regarded as an encouraging sign that this subject is being more widely taught in schools. The author of the present volume, who rightly deplores the little provision hitherto made, can feel that he has made a useful contribution for teaching a subject which he describes as one of absorbing interest and one in which lack of knowledge can lead to distorted views.

Dr. G. H. Bourne departs somewhat from the normal text-book pattern in approaching his subject from the historical angle. This approach is extremely well used in the chapters on blood, circulation and respiration; but in those on food, digestion and metabolism it gives a somewhat disjointed effect. The slighter treatment of other systems of the body is the penalty paid for using this unusual approach in a book of limited size. But it should be pointed out that, apart from the interest of the early history, this approach gives an opportunity of showing the spectacular results that have accrued from uniting the modern method of experiment with that of observation and speculation used by workers in this field in the early days.

W. C. C.

\section{Snow White}

The Story of a Polar Bear Cub. By Jan Vlasák and Josef Seget. Edited by Dr. Maurice Burton. Pp. viii + 88. (London, Edinburgh and Glasgow : William Hodge and Co., Ltd., 1949.) 12s. 6d. net.

$T$ HIS is a charming book which will appeal to children of all ages and even to those of us who are old in years but have remained children at heart. The story of the upbringing of the wee bear, a story which is illustrated by a series of delightful photographs, makes us admire the devotion of the human nurse, who had to be awake, to feed the cub from the bottle, at short intervals throughout the twenty. four hours. At her earliest stages the little bear resembles, in the photographs, a children's toy, yet there is great intelligence in her eyes even from the first.

The rearing of the little bear took place in an occupied country during the war years and was thus the more noteworthy. Hand-rearing was a last hope, for the mother had shown that she was unable to rear her cubs; yet it was difficult to take 'Snow White' from her. Her feeding had to be severely rationed, and on the rare occasion when the ration was exceeded (owing to 'Snow White's' pleading) the cub became ill-indeed, on one occasion her life was for a time despaired of. The book is well produced, and I can imagine no more acceptable present to give a child. 